\title{
Big emitters team up
}

\section{US-China clean-energy collaboration targets coal and cars.}

China and the United States have taken a small but significant step together towards reducing their energy consumption and greenhousegas emissions. On 2 September, US energy secretary Steven Chu announced the first projects of a bilateral programme, the USChina Clean Energy Research Center (CERC). Those involved admit that its US\$150-million budget is a tiny fraction of what will be needed to address both nations' growing energy demands, but say that it is important both as a symbolic effort, and because it paves the way for future collaboration.

CERC will have headquarters in each country and aims to develop and commercialize new technologies through public-private consortia. The first projects include a clean-vehicles collaboration, led by the University of Michigan in Ann Arbor, and involving major vehicle manufacturers; and a 'clean carbon' project led by West Virginia University in Morgantown, which will include efforts to trap emissions from coal-fired power stations using carbon capture and storage (CCS) systems. "Both countries rely heavily on coal resources," says Jerald Fletcher, director of the Natural Resource Analysis Center at West Virginia University and leader of the

\begin{tabular}{|l|l|}
\hline \multicolumn{2}{|l|}{ TOP 10 CLEAN-ENERGY } \\
INVESTORS & 2009 \\
\hline China & $\$ 34.6$ billion \\
\hline United States & $\$ 18.6$ billion \\
\hline United Kingdom & $\$ 11.2$ billion \\
\hline Rest of EU & $\$ 10.8$ billion \\
\hline Spain & $\$ 10.4$ billion \\
\hline Brazil & $\$ 7.4$ billion \\
\hline Germany & $\$ 4.3$ billion \\
\hline Canada & $\$ 3.3$ billion \\
\hline Italy & $\$ 2.6$ billion \\
\hline India & $\$ 2.3$ billion \\
\hline
\end{tabular}
that the United States and China, the two largest energy users and greenhouse-gas emitters, work together to address these issues."

A US consortium in clean buildings will be announced this autumn, and China is expected to announce parallel consortia in the same three fields soon. Each of the six consortia will receive $\$ 12.5$ million from the respective governments, to be matched by consortium members.

Dennis Assanis, director of the Michigan Memorial Phoenix Energy Institute and leader of the clean-vehicle project, says the two countries bring complementary skills. "Universities in the United States are known for high-calibre research and for demonstrating technology in the laboratory. Universities in China are strong at demonstrating technologies in full-vehicle prototypes," he says. "Because the United States and China are the biggest producers of vehicles globally, solutions we develop to

make transportation more environmentally friendly will make the biggest contribution to the environment."

"For the past decade, China has been saying, 'we want to do more joint research, we want you to come in and pay half'", says Deborah Seligsohn, a Beijing-based analyst for the World Resources Institute. "Someone finally took them up on it."

On the US side, planners hope that the projects will give a boost to green industries. According to Who's Winning the Clean Energy Race?, a March report from the Pew Charitable Trusts - non-profit policy analysts in Washington DC - China became the biggest investor in clean energy in 2009 (see table). Most of this money was spent on wind- and solar-power infrastructure; China already leads the world in manufacturing these components (see Nature 457, 372-374; 2009). Many other countries are now hoping to forge links with China's booming cleanenergy industry. Australia, for example, has allocated Aus\$20 million (US\$18 million) for collaboration on CCS; the United Kingdom has put $£ 11.49$ million (US\$17.7 million) into 14 ongoing projects on renewable-energy technologies and cleaner fossil fuels, and will announce further joint efforts on CCS, solar power and fuel cells in the coming months.

There are still many wrinkles to be ironed out with CERC. In contrast to the US open bidding system, the Chinese government is appointing its consortia, raising concerns among US partners about who they might be working with. And Ann Marie Sastry, a materials scientist and part of the University of Michigan's clean-vehicle consortium, says that as both nations compete for technology markets, there are likely to be tensions about the intellectual property generated by CERC.

"It's going to be awkward in the beginning," agrees Sabina Brady, executive director at the US-China Energy Cooperation Program, a business association representing 35 US companies in China, many of which are involved in the consortia. "CERC could be improved. But the important part of CERC is that it got started." David Cyranoski 